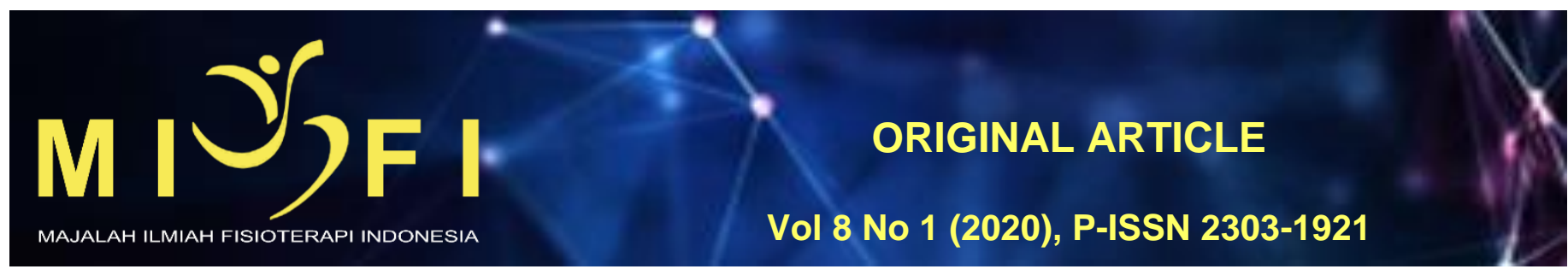

\title{
KECEPATAN LARI 40 METER PADA ANAK LAKI-LAKI USIA 10-12 TAHUN DENGAN NORMAL FOOT DAN FLAT FOOT DI SEKOLAH DASAR NEGERI 8 DAUH PURI
}

\author{
Ni Made Maya Risna Ayu ${ }^{1}$, Anak Ayu Trisna Nyoman Trisna Narta Dewi ${ }^{2}$, Agung Wiwiek Indrayani $^{3}$ \\ ${ }^{1}$ Program Studi Sarjana Fisioterapi dan Profesi Fisioterapi, Fakultas Kedokteran, Universitas Udayana \\ ${ }^{2}$ Departemen Fisioterapi, Fakultas Kedokteran, Universitas Udayana \\ ${ }^{3}$ Departemen Farmakologi dan Terapi, Fakultas Kedokteran, Universitas Udayana \\ nimademaya.nm@gmail.com
}

\begin{abstract}
ABSTRAK
Kemampuan lokomotor yang penting dimiliki oleh anak untuk melakukan aktivitas sehari-hari adalah kecepatan lari. Kecepatan lari dipengaruhi oleh berbagai kondisi, salah satunya yaitu kondisi flat foot. Kondisi flat foot mengakibatkan terjadinya hiperpronasi forefoot yang akan mengurangi kecepatan lari. Tujuan penelitian ini untuk mengetahui perbedaan kecepatan lari 40 meter pada anak laki-laki usia 10-12 tahun dengan normal foot dan flat foot. Rancangan penelitian menggunakan cross sectional analitik dengan total sampel 48 orang dan dilakukan pada bulan Maret 2019. Penelitian dilakukan dengan memeriksa bentuk arkus pedis normal foot dan flat foot menggunakan Staheli Arch Index dan mengukur kecepatan lari menggunakan lintasan lari sepanjang 40 meter. Teknik analisis data yang dilakukan yaitu uji normalitas menggunakan Shapiro Wilk Test dan uji hipotesis Independent T Test untuk mengetahui perbedaan nilai kecepatan lari pada kelompok normal foot dan flat foot. Hasil Independent $T$ Test mendapatkan nilai $p=0,003(p<0,05)$ yang berarti terdapat perbedaan kecepatan lari 40 meter yang signifikan pada kelompok normal foot dan flat foot. Hasil penelitian juga menunjukkan nilai rerata kecepatan lari pada kelompok normal foot dan flat foot masing masing 8,18 $\pm 0,61$ dan 8,87 $\pm 0,88$. Simpulan penelitian ini adalah terdapat perbedaan kecepatan lari 40 meter pada anak laki-laki usia 10-12 tahun dengan normal foot dan flat foot, dimana kelompok normal foot memiliki kecepatan yang lebih tinggi dibandingkan kelompok flat foot
\end{abstract}

Kata Kunci: flat foot, normal foot, kecepatan lari 40 meter, usia 10-12 tahun, staheli arch index

\section{THE DIFFERENCE RUNNING SPEED OF 40 METERS BETWEEN NORMAL FOOT AND FLAT FOOT OF BOYS AGED 10-12 YEARS OLD AT 8 DAUH PURI ELEMENTARY SCHOOL}

The important locomotor skill possessed by children to carry out activities is running speed. Flat foot conditions affect the child's running speed. Hyperpronation forefoot which occurs on flat foot will reduce running speed. The purpose of this study was to investigate the difference in running speed of 40 meters in boys aged 10-12 years with normal foot and flat foot. The study design used a cross-sectional analytic with total sample of 48 people and was conducted in March 2019. The study was conducted by examining the Staheli Arch Index and measure the running speed using a 40-meters running track. The data analysis technique used was the normality test using the Shapiro Wilk Test and the hypothesis test using Independent T-Test to test the difference in running values in groups of normal feet and flat feet. The Independent T-Test results obtained a value of $p=0,003(p<0,05)$ which were there are a significant 40-meters running speed in the group of the normal foot and flat foot. The results of the study also showed that the average running speed in the normal foot group and flat foot group were $8,18 \pm 0,61$ and $8,87 \pm 0,88$. The conclusion of this study shows that there are the difference of 40-meters running speed in boys aged 10-12 years with normal foot and flat foot, where the normal foot group has a higher speed than the flat foot group.

Keywords: flat foot, normal foot, 40-meters running speed, 10-12 years old, staheli arch index 


\section{PENDAHULUAN}

Anak anak usia sekolah dasar mengalami perkembangan fisik maupun mental. Perkembangan fisik yang dialami oleh anak sekolah dasar salah satunya yaitu perkembangan motorik kasar. Salah satu perkembangan motorik kasar yang dimiliki anak untuk melakukan aktivitas sehari-hari adalah kemampuan lokomotor. Kemampuan lokomotor yaitu kemampuan yang dimiliki oleh seseorang untuk berpindah tempat dari satu titik ke titik lainnya. ${ }^{1}$

Salah satu komponen kemampuan lokomotor yang penting bagi anak adalah kemampuan berlari. Kemampuan ini dapat diketahui dengan mengukur kecepatan lari. ${ }^{2}$ Kecepatan lari merupakan kemampuan yang dimiliki seseorang untuk melakukan gerakan yang saling berkesinambungan dalam waktu yang sesingkat-singkatnya. Salah satu faktor yang mempengaruhi kecepatan lari adalah kondisi flat foot. ${ }^{3}$ Flat foot merupakan suatu keadaan abnormal yang dialami oleh seseorang dimana arkus longitudinal menjadi datar. Sebuah penelitian di Austria menunjukkan prevalensi anak yang memiliki flat foot pada usia $3-6$ tahun sejumlah $44 \% .{ }^{4}$ Penelitian lain di Surakarta menunjukkan prevalensi anak usia 6 - 12 tahun yang memiliki flat foot sebesar $27,5 \% .{ }^{25}$ Prevalensi flat foot pada anak laki-laki usia 3-6 tahun sebesar $52 \%$ sedangkan pada perempuan sebesar $36 \% .^{5}$

Penderita flat foot"memiliki bentuk kaki dimana terjadi valgus pada hindfoot, dorsofleksi dan abduksi pada midfoot serta pronasi"dan eksternal rotasi padal forefoot sehingga mengakibatkan arkus longitudinal medial menjadi datar. ${ }^{5}$ Pronasi yang berlebihan akan menghambat kemampuan manusia saat berdiri, berjalan dan berlari. ${ }^{6}$ Bayi pada normalnya tidak memiliki arkus karena pertumbuhan arkus terjadi selama satu dekade pertama kehidupan anak. ${ }^{4}$ Arkus pedis berfungsi untuk membantu menahan beban berat badan serta membantu dalam proses berjalan dan berlari. ${ }^{7}$ Salah satu jaringan yang membentuk arkus pedis yaitu plantar aponeurosis atau plantar fascia. Plantar aponeurosis merupakan suatu jaringan ikat fascia yang tebal dan memiliki fungsi untuk menyangga arkus longitudinal dan mampu menyerap sekitar $60 \%$ berat badan. ${ }^{8}$ Fungsi lain dari plantar aponeurosis adalah membantu arkus pedis menjadi gaya pegas dalam proses berjalan dan berlari yang dikenal dengan mekanisme windlass effect. Plantar aponeurosis akan menegang saat fase push off dalam gait cycle sehingga akan meningkatkan arkus longitudinal medial. Peningkatan arkus longitudinal medial akan menstabilkan pergerakan pada saat distribusi berat badan terjadi di seluruhnya metatarsal sehingga akan meningkatkan kecepatan lari. ${ }^{9}$ Sebuah penelitian menunjukkan seseorang dengan arkus tinggi memiliki keseimbangan dinamis dan kecepatan yang lebih baik dibandingkan dengan seseorang yang memiliki arkus rendah. ${ }^{5}$

Melihat betapa pentingnya arkus pedis terhadap kemampuan berjalan dan berlari, maka dalam penelitian ini akan dilakukan penelitian terkait hubungan arkus pedis dengan kecepatan berlari. Bentuk arkus pedis yang akan diteliti yaitu bentuk arkus pes planus/flat foot dan normal foot karena prevalensi jumlah anak-anak yang mengalami flat foot cukup besar. Jumlah anak yang mengalami flat foot lebih banyak ditemukan pada anak laki-laki. Pertumbuhan arkus terjadi selama dekade pertama kehidupan anak, jadi dapat dikatakan apabila anak dengan usia dibawah 10 tahun mengalami flat foot, maka hal tersebut masih menjadi sebuah proses fisiologis yang terjadi pada pertumbuhan anak. Hasil dari penelitian ini nantinya dapat memberikan sebuah edukasi terkait pencegahan serta deteksi dini kondisi flat foot pada anak.

\section{METODE}

Penelitian dilakukan dengan rancangan cross sectional analitik. Penelitian ini dilakukan dengan melakukan assessment dan pengukuran pada setiap sampel penelitian yang dilakukan hanya dalam satu kali pengukuran. Penelitian ini dilaksanakan di SDN 8 Dauh Puri Denpasar.

Pengambilan sampel dilakukan dengan teknik simple random sampling yang telah memenuhi kriteria inklusi dan eksklusi penelitian diantaranya anak berjenis kelamin laki-laki dengan usia 10-12 tahun dengan normal foot dan flat foot; memiliki Indeks Massa Tubuh (IMT) normal; nilai panjang tungkai $69-80 \mathrm{~cm}$; nilai kekuatan otot tungkai sebesar 28-68 kg; memiliki pola makan dengan frekuensi makan $2-4$ kali sehari, dimana konsumsi karbohidrat, protein, lemak dan vitamin $>1 \mathrm{x} /$ hari. Total sampel dalam penelitian ini yaitu 48 siswa dengan masing-masing 24 siswa untuk kelompok normal foot dan kelompok flat foot. Variabel terikat pada penelitian ini adalah bentuk arkus pedis normal foot dan flat foot sedangkan variabel bebas adalah kecepatan lari 40 meter.

Bentuk arkus pedis diperiksa dengan menggunakan Staheli Arch Index yang dilakukan dengan cara melangkahkan kaki yang akan diperiksa keatas podograph yang dibawahnya telah dilapisi kertas sehingga bentuk kaki akan tercetak. Hasil pemeriksaan dihitung dengan membagi regio A dan B untuk menunjukkan bentuk arkus pedis sesuai dengan kategori usianya. Normal foot merupakan kondisi apabila nilai hasil antara regio A dan B berada diantara 0,4 sampai 1,0 sementara kondisi flat foot apabila nilai hasil bagi regio $A$ dan $B$ lebih dari 1,0.

Kecepatan lari diukur dengan menggunakan tes kecepatan lari 40 meter. Tes ini dilakukan untuk mengetahui kecepatan lari anak kategori usia 10-12 tahun yang telah ditetapkan pada Tes Kesegaran Jasmani Indonesia (TKJI). Kecepatan lari diketahui dengan waktu dalam detik yang dapat ditempuh oleh sampel selama berlari dengan jarak 40 meter.

Data yang telah didapatkan pada penelitian ini kemudian akan dianalisis dengan uji statistika deskriptif untuk mengetahui distribusi karakteristik sampel, uji Shapiro Wilk Test dan Levene Test untuk menguji sebaran kenormalan dan homogenitas data dan dilanjutkan dengan uji hipotesis Independent T Test untuk mengetahui perbedaan kecepatan lari 40 meter antara kelompok normal foot dan flat foot menggunakan aplikasi SPSS (Statistical Program for Social Science) versi 20.0 .

\section{HASIL PENELITIAN}

Total sampel yang berjumlah 48 orang dibagi menjadi dua kelompok yaitu 24 orang kelompok normal foot dan 24 orang kelompok flat foot. Distribusi karakteristik sampel dilakukan berdasarkan karakteristik indeks massa tubuh (IMT), kekuatan otot, panjang tungkai dan usia. 
Tabel I. Distribusi Karakteristik Sampel

Berdasarkan IMT, Kekuatan Otot dan Panjang Tungkai

\begin{tabular}{ll}
\multicolumn{1}{c}{ Variabel } & Rerata \pm SB \\
\hline IMT $\left(\mathrm{kg} / \mathrm{m}^{2}\right)$ & $18,34 \pm 2,04$ \\
Kekuatan Otot $(\mathrm{kg})$ & $45,14 \pm 12,04$ \\
Panjang Tungkai $(\mathrm{cm})$ & $74,11 \pm 3,64$
\end{tabular}

Berdasarkan Tabel I diketahui bahwa rerata indeks massa tubuh pada sampel yang berjumlah 48 orang yaitu sebesar $18,34 \mathrm{~kg} / \mathrm{m}^{2}$. Nilai rerata panjang tungkai sebesar $74,11 \mathrm{~cm}$. Terakhir, nilai rerata kekuatan otot sebesar 45,14 $\mathrm{kg}$. Ketiga variabel tersebut termasuk kedalam kriteria inklusi pada penelitian ini.

\section{Gambar I. Distribusi Frekuensi Karakteristik Sampel Berdasarkan Usia}

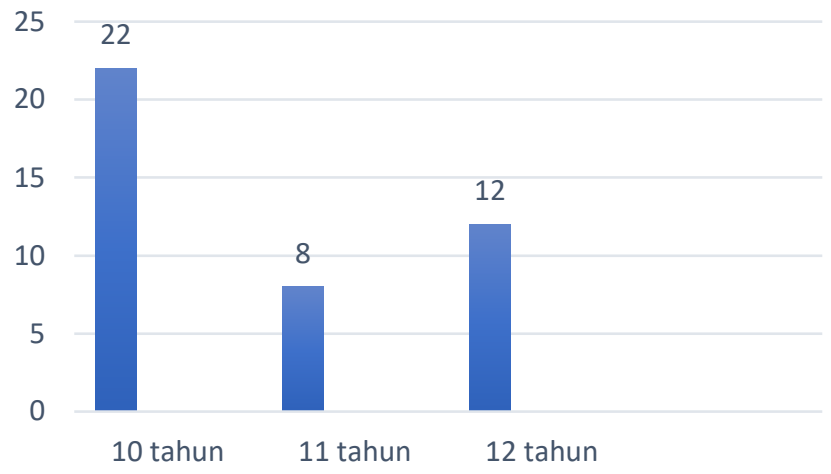

Berdasarkan Gambar I diketahui jumlah sampel terbanyak dalam penelitian ini ialah siswa usia 10 tahun yakni sejumlah 22 orang $(45,8 \%)$ dan sebaliknya, jumlah sampel terkecil ialah siswa usia 11 tahun sejumlah 8 orang $(16,7 \%)$.

Tabel II. Hasil Uji Normalitas

\begin{tabular}{ccc}
\hline Kelompok & Rerata \pm SB & $\mathbf{p}$ \\
\hline Normal Foot (detik) & $8,18 \pm 0,61$ & 0,080 \\
Flat Foot (detik) & $8,87 \pm 0,88$ & 0,667 \\
\hline
\end{tabular}

Berdasarkan Tabel II diketahui hasil uji normalitas menggunakan Shapiro Wilk Test pada kelompok normal foot memiliki nilai signifikansi $p=0,080(p>0,05)$ dan kelompok flat foot nilai $p=0,667(p>0,05)$ sehingga dapat disimpulkan kelompok normal foot dan flat foot memiliki data yang berdistribusi normal

Tabel III. Hasil Uji Homogenitas

\begin{tabular}{cccc}
\hline Levene Statistic & df1 & df2 & $\mathbf{p}$ \\
\hline 3,912 & 1 & 46 & 0,054 \\
\hline
\end{tabular}

Hasil nilai p>0,05 menunjukan bahwa data nilai kecepatan lari 40 meter pada kelompok normal foot dan flat foot bersifat homogen.

Tabel IV. Uji Perbedaan Kecepatan Lari 40 Meter pada Kelompok Normal Foot dan Flat Foot

\begin{tabular}{ccc}
\hline Kelompok & Rerata \pm SB & $\mathbf{p}$ \\
\hline Normal Foot (detik) & $8,18 \pm 0,61$ & \multirow{2}{*}{0,003} \\
Flat Foot (detik) & $8,87 \pm 0,88$ & \\
\hline
\end{tabular}

Berdasarkan hasil uji pada Tabel IV diketahui kecepatan lari 40 meter pada kelompok normal foot lebih tinggi dibandingkan dengan kecepatan lari 40 meter pada kelompok flat foot. Kelompok normal foot memiliki nilai rerata kecepatan 8,18 detik dan kelompok flat foot memiliki nilai rerata 8,87 detik

Hasil analisis yang dilakukan dengan menggunakan Independent $T$ - Test mendapatkan nilai signifikansi $\mathrm{p}=0,003$ $(p<0,05)$. Hal ini menunjukkan bahwa terdapat perbedaan kecepatan lari 40 meter yang signifikan pada kelompok normal foot dan flat foot.

\section{DISKUSI \\ Karakteristik Sampel}

Karakteristik sampel pada penelitian ini diketahui berdasarkan hasil analisis data yang telah dilakukan terhadap karakteristik usia, indeks massa tubuh (IMT), kekuatan otot tungkai serta panjang tungkai. Sampel dalam penelitian ini merupakan anak berjenis kelamin laki-laki dengan usia 10-12 tahun. Anak laki-laki usia 10-12 tahun mengalami kematangan fisik yang diikuti oleh peningkatan perkembangan motorik kasar salah satunya kemampuan berlari yang akan berpengaruh terhadap aktivitas sehari-hari anak. Anak laki-laki memiliki kekuatan otot serta lonjakan pertumbuhan panjang tungkai dan lengan yang lebih signifikan dibandingkan perempuan. ${ }^{10}$ Jenis kelamin juga memiliki hubungan dengan kejadian flat foot. Sebuah penelitian menunjukkan prevalensi flat foot pada anak perempuan sebesar $36 \%$ sedangkan pada laki-laki sebesar 52\%. ${ }^{4}$ Secara fisiologis, usia 10-12 tahun telah memiliki bentuk arkus pedis yang 
normal. Hal ini disebabkan karena penelitian mengungkapkan bahwa perkembangan arkus longitudinal akan meningkat dengan cepat pada usia 5 sampai 6 tahun dan akan berhenti pada masa pra sekolah atau usia 10 tahun. ${ }^{11}$

Seluruh sampel dalam penelitian ini memiliki indeks massa tubuh (IMT) normal dengan nilai rerata (18,34 $\pm 2,04)$

$\mathrm{kg} / \mathrm{m} 2$. Hubungan antara indeks massa tubuh (IMT) dengan kecepatan lari berbanding terbalik. Kecepatan lari akan menurun seiring dengan peningkatan indeks massa tubuh. ${ }^{12}$ Indeks massa tubuh juga memiliki hubungan dengan flat foot. Anak dengan obesitas dan overweight memiliki kecenderungan lebih besar untuk mengalami flat foot dibandingkan anak dengan indeks massa tubuh (IMT) normal. ${ }^{26}$

Nilai kekuatan otot dan panjang tungkai didapatkan dengan menghitung nilai rerata \pm 1SB pada populasi terjangkau sehingga memenuhi kriteria inklusi sebagai sampel penelitian. Seluruh sampel pada penelitian ini memiliki nilai kekuatan otot dan nilai panjang tungkai sesuai dengan kriteria inklusi tersebut. Nilai rerata kekuatan otot tungkai sampel yaitu $(45,14 \pm 12,04) \mathrm{kg}$. Selanjutnya, nilai rerata panjang tungkai yang dimiliki sampel yaitu $(74,11 \pm 3,64) \mathrm{cm}$. Kecepatan lari dipengaruhi oleh stride length. Stride length dipengaruhi oleh panjang tungkai serta kekuatan otot otot ekstensor tungkai bawah yang membantu tubuh kedepan sehingga semakin tinggi nilai panjang tungkai dan kekuatan otot tungkai, maka stride length akan meningkat dan akan berdampak pada peningkatan kecepatan lari. Hubungan mengenai kekuatan otot dan kecepatan lari juga dapat dijelaskan menurut hukum percepatan, percepatan lari berbanding lurus dengan kekuatannya, sehingga semakin tinggi kekuatan otot maka semakin tinggi pula percepatan pelari. ${ }^{14}$

\section{Perbedaan Kecepatan Lari $\mathbf{4 0}$ Meter pada Kelompok Normal Foot dan Flat Foot}

Perbedaan kecepatan lari 40 meter pada kelompok normal foot dan flat foot diketahui berdasarkan hasil uji Independent T Test. Nilai rerata kecepatan lari pada kelompok normal foot $(8,18 \pm 0,61)$ detik sedangkan nilai rerata kecepatan lari pada kelompok flat foot $(8,87 \pm 0,88)$ detik. Hasil uji ini mendapatkan nilai $p$ sebesar $p=0,003(p<0,05)$ sehingga dapat disimpulkan bahwa terdapat perbedaan kecepatan lari yang signifikan pada kelompok normal foot dan flat foot. Penelitian ini menunjukkan kecepatan lari pada kelompok normal foot lebih tinggi dibandingkan kecepatan lari pada kelompok flat foot.

Penelitian yang selaras dengan hasil penelitian ini yaitu penelitian yang dilakukan dengan mengukur kecepatan lari 40 yard pada kelompok normal foot, flat foot dan cavus foot. Penelitian tersebut menunjukkan terdapat perbedaan kecepatan lari jarak pendek yang signifikan pada ketiga kelompok. Kecepatan lari akan meningkat apabila pelari tersebut menghabiskan waktu kurang dari $22 \%$ pada stance phase. Kecepatan juga akan meningkat apabila initial contact berubah dari hindfoot menuju forefoot. Normal foot dan cavus foot memiliki waktu perubahan initial contact ke forefoot lebih cepat dibandingkan flat foot. Hal inilah yang menyebabkan terjadinya penurunan kecepatan lari pada kelompok flat foot. ${ }^{3}$

Penelitian sebelumnya yang dilakukan pada tahun 2016 oleh Sharma et al. juga mendapatkan hasil perbedaan kecepatan lari 100 meter yang signifikan pada kelompok normal foot dan flat foot. Hal ini disebabkan karena lari 100 meter yang tergolong dalam lari sprint yang merupakan aktivitas eksplosif sehingga dibutuhkan reaction force dan kekuatan otot yang lebih besar. ${ }^{6}$ Aktivasi otot intrinsik menurun seiring dengan penurunan struktur navicular. Kondisi flat foot mengalami penurunan struktur navicular sehingga mengakibatkan kelemahan otot intrinsik. Otot intrinsik memiliki fungsi untuk stabilisasi regio tarsal dan metatarsal. Otot ini juga menyokong arkus longitudinal medial dan akan teraktivasi selama gait cycle untuk mengatur gerakan pronasi sehingga tidak terjadi overpronasi. ${ }^{14}$ Otot abductor hallucis merupakan bagian dari otot intrinsik yang membantu stabilisasi arkus longitudinal medial saat bergerak bersama dengan otot flexor hallucis longus dan interosseous. Kelemahan otot abductor hallucis mengakibatkan peningkatan pronasi sehingga akan terjadi penurunan navicular. Latihan penguatan otot abductor hallucis dapat meningkatkan arkus longitudinal medial. ${ }^{22}$ Penelitian lain yang dilakukan pada tahun 2009 oleh Gani et al. menunjukkan bahwa terdapat hubungan antara tinggi arkus pedis dengan kemampuan berlari meskipun dalam korelasi yang sangat rendah. Hal ini disebabkan karena pada penelitian tersebut tidak memperhitungkan dan mengontrol indeks massa tubuh (IMT). ${ }^{7}$

Flat foot merupakan suatu kondisi abnormal dimana terjadi penurunan arkus longitudinal medial dan akan berdampak pada perubahan struktur pedis. Flat foot mengakibatkan regio forefoot atau midfoot menjadi pronasi dan abduksi yang berlebihan. ${ }^{15}$ Kondisi ini juga akan mengakibatkan terjadinya kelemahan pada tendon tibialis posterior serta overstretch pada plantar fascia. Plantar fascia memiliki fungsi sebagai penyokong pasif utama untuk mempertahankan tinggi arkus pedis, menstabilkan serta menguatkan regio forefoot dan midfoot. Kondisi flat foot mengakibatkan overstretch plantar fascia sehingga struktur tersebut tidak dapat mempertahankan tinggi arkus pedis dan arkus akan "drop". ${ }^{9}$ Keadaan ini akan mengakibatkan regio midfoot dan forefoot menjadi tidak stabil dan berdampak pada perubahan initial contact saat berlari. Kecepatan berlari akan meningkat seiring dengan peningkatan perubahan initial contact dari regio heel menuju regio midfoot atan forefoot. Perubahan initial contact yang terjadi pada flat foot tidak berlangsung sebaik normal foot sehingga akan mengurangi kecepatan lari. ${ }^{16}$

Kondisi flat foot juga menyebabkan disfungsi tendon tibialis posterior yang disebut tendinopathy dan mengakibatkan kelemahan jaringan penyokong di sekitar pedis serta berdampak pada perubahan struktur sehingga terjadi pronasi yang berlebihan pada pedis. ${ }^{17}$ Otot tibialis posterior memiliki fungsi sebagai penyokong arkus pedis dengan bantuan tendon tibialis posterior dan mencegah pronasi pada subtalar setelah heel contact. ${ }^{18}$ Pronasi yang berlebihan akan mempengaruhi fase push off yang terjadi dalam biomekanik berjalan dan berlari. ${ }^{19}$ Saat fase push off, pronasi yang berlebihan mengakibatkan ketidakstabilan struktur pedis, sedangkan seharusnya pada fase ini dibutuhkan stabilisasi yang baik sehingga terjadi dorongan kedepan pada tungkai untuk meningkatkan kecepatan lari. Pronasi yang berlebihan pada forefoot juga akan mengakibatkan terjadinya peningkatan ground reaction force pada bagian medial tibia. Hal ini akan mengakibatkan otot bekerja lebih keras sehingga akan menyebabkan kelelahan otot dan 
mempengaruhi kemampuan berlari. ${ }^{16}$ Disfungsi tendon tibialis posterior juga dapat mengakibatkan peningkatan ketegangan otot tibialis posterior dan meningkatkan resiko terjadinya cedera. ${ }^{18}$

Kemampuan berlari merupakan bagian dari kemampuan lokomotor yang dibutuhkan bagi setiap individu termasuk anak-anak. Kemampuan berlari dapat diketahui dengan mengukur kecepatan berlari. Peningkatan kecepatan lari ditentukan oleh cadence, stride length dan step length. Cadence merupakan jumlah langkah setiap menit, sedangkan stride length merupakan jarak antara initial contact pada kaki yang sama dan terakhir step length merupakan jarak initial contact antara kaki satu dengan kaki yang lainnya. Peningkatan kecepatan terjadi saat step length meningkat dan diikuti juga oleh peningkatan cadence. Peningkatan ini akan membuat float phase menjadi lebih lama. ${ }^{16}$

Penelitian yang dilakukan pada tahun 2008 oleh Williams et al. menunjukkan bahwa terdapat hubungan antara kemampuan lokomotor terhadap tingkat aktivitas fisik anak, dimana aktivitas fisik anak akan meningkat apabila memiliki anak kemampuan lokomotor yang baik. Aktivitas fisik yang baik akan menyebabkan anak menjadi lebih aktif untuk melakukan kegiatan sehari hari seperti bermain, belajar serta berolahraga. ${ }^{20}$ Kemampuan lokomotor merupakan kemampuan seseorang untuk berpindah dalam segala arah dari satu titik ke titik lainnya. Beberapa gerakan yang tergolong kedalam kemampuan lokomotor yaitu berjalan, berlari, menghindar, melompat, meluncur, dan skipping. Berlari merupakan bentuk kemampuan lokomotor yang memiliki fase melayang dan terjadi apabila tubuh condong ke depan bersamaan dengan pergantian kaki. Berlari merupakan gerakan lanjutan dari berjalan. Gerakan berlari dapat dilakukan oleh anak apabila anak sudah mampu berjalan. ${ }^{25}$ Penelitian lain juga menjelaskan mengenai hubungan antara flat foot dengan aktivitas fisik pada anak. Anak yang mengalami flat foot akan memiliki level aktivitas yang rendah. Hal ini dapat disebabkan karena anak flat foot kurang melakukan aktivitas olahraga dan latihan penguatan otot kaki seperti bermain bola, berlari, bermain basket dan sebagainya. ${ }^{21}$

Kondisi flat foot tidak hanya berdampak pada kemampuan berlari anak. Sebuah penelitian mengungkapkan bahwa flat foot akan mempengaruhi keseimbangan seseorang. Hal ini disebabkan karena keseimbangan membutuhkan stabilisasi yang kuat pada regio ekstremitas bawah, dimana akan terganggu apabila sendi dan struktur yang berada pada pedis tidak kuat. Flat foot juga mempengaruhi kemampuan lainnya seperti kelincahan, meningkatkan resiko terjadinya plantar fasciitis serta patellofemoral pain syndrome. ${ }^{22}$

Pada penelitian ini terlihat bahwa terdapat perbedaan kecepatan lari 40 meter pada anak laki-laki dengan normal foot dan flat foot, dimana anak dengan flat foot memiliki kecepatan lari yang lebih rendah dibandingkan anak dengan normal foot. Dampak flat foot terhadap penurunan kecepatan lari pada anak yang juga berpengaruh terhadap penurunan perkembangan motorik anak. Anak usia 10-12 tahun mengalami peningkatan dalam kemampuan dalam berolahraga seperti sepak bola yang membutuhkan kecepatan lari. Melihat pentingnya kecepatan berlari bagi anak, maka perlu ditingkatkannya kesadaran untuk mencegah dan menangani salah satu faktor resiko yang mempengaruhi kecepatan berlari yaitu flat foot. Penanganan yang optimal perlu dilakukan untuk memperbaiki struktur arkus longitudinal medial tersebut serta melatih otot-otot pedis baik otot ekstrinsik maupun intrinsik dengan cara latihan penguatan otot pedis dan penggunaan sepatu yang memiliki arch support sehingga anak sekolah dasar dapat melakukan aktivitas sehari-hari tanpa hambatan.

\section{SIMPULAN}

Berdasarkan hasil analisis data yang telah dilakukan dan pembahasan yang telah dipaparkan, maka simpulan dalam penelitian ini yaitu terdapat perbedaan kecepatan lari 40 meter pada anak laki-laki usia 10-12 tahun dengan normal foot dan flat foot, dimana kecepatan lari anak dengan normal foot lebih tinggi dibandingkan anak dengan flat foot.

\section{DAFTAR PUSTAKA}

1. Nicolae M and Liliana M. The Management of Scientic Research Project. Journal of Physical Education and Sport. 2010;26(1):19-24

2. Baskoro JC, Sugiyanto and Doewes Muchsin. Perkembangan Kemampuan Melempar Dan Berlari Pada AnakAnak Usia 7 Sampai Dengan 12 Tahun Ditinjau Dari Jenis Kelamin. [Tesis]. Surakarta : Universitas Sebelas Maret; 2014.

3. Sudhakar, S., Kirthika, S V., Padmanabhan, K., Kumar, G. Mohan., Nathan, C V S., Gopika, R., Samuel, A J.. Impact of Various Foot Arches on Dynamic Balance and Speed Performance in Collegiate Short Distance Runners: A Cross-sectional Comparative Study. J of Orthopaedics. Elsevier. 2018; 15(1):114-117.

4. Pfeiffer M, Kotz R, Ledl T, Hauser G and Sluga M. Prevalence of Flat Foot in Preschool-Aged Children. Pediatrics. 2006; 118(2):634-639.

5. Carr JB, Yang S and Lather LA. Pediatric Pes Planus: A State-of-the-Art Review. Pediatrics. 2016; 137(3):1-8

6. Sharma, J. and Upadhyaya, P. Effect of Flat Foot on the Running Ability of an Athlete. Indian Journal of Orthopaedics Surgery. 2016; 2(1):119

7. Gani, AB and Patellongi I. Hubungan Arcus Pedis dengan Kemampuan Lari Siswa SMP Negeri 23 Makassar. Jurnal Madani FKM UMI. 2009; 2(3):142-3.

8. Drake, RL, Vogl, A and Mitchell, AWM. Gray's Anatomy For Student Third Edition. Canada : Elsevier Inc; 2013

9. Neumann, DA. Kinesiology Of The Musculoskeletal System: Foundations for Rehabilitation. United States : Elsevier Mosby; 2010. p.593-604

10. Setiawan DK and Muhammad HN. Survei Kemampuan Motorik Siswa Sekolah Dasar Negeri Tahun Ajaran 20142015. Jurnal Pendidikan Olahraga dan Kesehatan. 2017; 5(1):12-20

11. Fritz B and Mauch M. Handbook of Footwear Design and Materials. Germany : University of Tuebingen; 2013

12. Utari, A. Hubungan Indeks Massa Tubuh dengan Tingkat Kesegaran Jasmani Pada Anak Usia 12-14 Tahun. [Tesis]. Semarang: Universitas Diponegoro; 2007 
13. Muliani. Biomekanika Lari. Denpasar : Universitas Udayana; 2016

14. Saikia P, Dutta A, Ujwal B, Boruah K. Effectiveness of Intrinsic Muscle Strengthening with Orthosis Over Conventional Physiotherapy with Orthosis for Navicular Drop in Prolong Standing Workers. Int J Physiother. 2015; 2(4):610-618.

15. Sung, K. and Yu, I. Acquired Adult Flatfoot: Pathophysiology, Diagnosis and Nonoperative Treatment. J Korean Foot Ankle Soc. 2015; 18 (3):87-92

16. Dugan SA and Bhat KP. Biomechanics and Analysis of Running Gait. Physical Medicine and Rehabilitation Clinics of North America. 2005; 16(3): 603-621

17. Pelletier-galarneau, M., Martineau, Patrick., Gaudreault, Maxime and Pham Xuan. Review of Running Injuries of the Foot and Ankle : Clinical Presentation and SPECT-CT Imaging Patterns. Am J Nucl Med Mol Imaging. 2015; 5(4):305-316

18. Kesson, Monica and Atkins, Elaine. Orthopaedics Medicine :A Practical Approach. Italy : Elsevier Butterworth Heinemann; 2005.

19. Donatelli, Robert and Wooden, Michael J. Orthopaedics Physical Therapy. United State of America : Churcill Livingstone Inc; 1989

20. Williams, HG, Pfeiffer KA, Neill JRO, Dowdal M, Mclver KL, Brown WH and Pate RR. Motor Skill Performance and Physical Activity in Preschool Children. Journal Obesity. 2008; 16(6):1421-1426

21. Janice Jasrin, C., Mayasari, W. and Eva Rakhmilla, L. Relationship between Physical Activity and Age on Flatfoot in Children. Althea Medical Journal. 2016; 3(3): 396-400

22. El-shamy, FF and Ghait, AS. Effect of Flexible Pes Planus on Postural Stability in Adolescent Females. International Journal of Science and Research. 2014; 3(7) : 2012-2015.

23. Dandy, David J. and Edwards, Dennis J. Essential Orthopaediccs and Trauma. Cambridge:Elsevier Sciene Limited; 2003.

24. Wardanie, S. 'Prevalensi Kelainan Bentuk Kaki (Flat Foot) Pada Anak Usia 6 - 12 Tahun Di Kota Surakarta'. [Skripsi]. Surakarta: Universitas Muhammadiyah Surakarta; 2013.

25. Anonim. Developing Fundamental Movement Skill Manual. [Internet] Available at: www.sportnz.org.nz. 2012 Diakses pada 20 Desember 2018

26. Pauk J, Ezerskiy V, Raso JV and Rogalskli M. Epidemiologic Factors Affecting Plantar Arch Development in Children with Flat Feet. Journal of the American Pediatric Medical Association. 2012; 102(2):114-1 